\title{
O diabo provavelmente: \\ luto e cisão comunitária em A hora da estrela, de Clarice Lispector
}

Resumo: Leitura de A hora da estrela, de Clarice Lispector, este ensaio analisa as fraturas politicas e retóricas que atravessam a trama do livro, tomando como ponto de partida as estratégias intrusivas e autodesqualificadoras de seu narrador.

Palavras-chave: Comunidade, Alteridade, Representação.

"Il ont prendit que tu serais/ un jour plus haut que tous les rois"

Guillaume Bouché, "Horoscope d'un pendu"

Composto por segmentos dissonantes e assimétricos, sempre conduzidos por uma voz que oscila de forma imprevisível entre o sadismo e a condescendência, entre a distância total e desesperadas tentativas de aproximação, A hora da estrela, de Clarice Lispector, apresenta sem dúvida o mais ousado 
embate da autora com o temário comumente associado ao romance brasileiro de 30, ao eleger como foco a trajetória de uma jovem nordestina que acaba morta por atropelamento no Rio de Janeiro. Personagem que constitui uma súmula perfeita da miséria social brasileira - desde a adolescência passada sob o jugo sádico de uma tia beata até a série de encontros fracassados que constituem o seu périplo na grande cidade -, a figura simultaneamente esquiva e familiar de Macabéa, alagoana de corpo cariado, fanática por Marilyn Monroe e goiabada com queijo, parece deixar pouco espaço para as iluminações profanas da primeira Clarice, emoldurada que se acha agora numa prosa que elege por matériaprima a massa de clichês e cacoetes regressivos do senso comum. Ao mesmo tempo, na esteira do que se tornará nota dominante em muito da melhor ficção brasileira de recorte social - veio que encontra talvez em Vidas secas sua amostra mais emblemática -, esse esforço de dar rosto e lastro ao corpo fragmentado da nação, tomando por eixo os desencontros entre a jovem nordestina e uma "cidade feita toda contra ela", surge aqui contrabalançado pela lucidez em torno dos impasses que cercam a tentativa de formalizar ficcionalmente um outro irredutível, sem que isso implique em transformá-lo em refém de um sistema de projeções prévias. Contudo, se, na obra-prima de Graciliano Ramos, esse desafio se traduzia no deliberado embaralhar desse outro e da voz em terceira pessoa - tendo sempre como pivô a flutuação provocada pelos mergulhos introspectivos em discurso indireto livre, até culminar na atordoante hipérbole de inverossimilhança que é o monólogo interior da cadela Baleia -, no caso do livro protagonizado por Macabéa, essa dificuldade encontra seu principal correlato na incômoda volubilidade e desajeito do narrador masculino Rodrigo S. M., com suas iniciais que são como uma indisfarçada piscada de olho para o leitor atento. Capaz de contrair e dilatar a seu bel-prazer a velocidade da história, num registro que conhece talvez seu momento mais forte na longa suspensão que assinala a morte de Macabéa, trata-se de uma voz que - com sua compulsão a interromper o curso dos fatos para comentá-los - não faz qualquer esforço em disfarçar sua falta de gentileza com a protagonista, tratada por vezes como um carretel a ser arremessado e puxado de volta ao sabor dos instáveis humores de seu demiurgo. Em não poucas passagens do livro, aliás, é um demiurgo que mal consegue segurar a vontade de livrar-se em definitivo do seu brinquedo incômodo, embora isso só venha a acontecer de fato na última dezena de páginas. Numa tocada que salta sem maiores avisos do falsete esganiçado ao grave cavernoso, é curioso perceber ainda como a deliberada exibição de onipotência 
dos primeiros parágrafos - nos quais Rodrigo realiza uma sinistra e pretensiosa paródia do narrador do Gênesis - corre de par com um tom que lembra mais o de um mestre de cerimônias de um show de variedades, com direito até a trilha para marcar e preparar melhor o sentido das cenas - e uma verve que não poupa sequer a morte de Macabéa. Desfecho por sinal já antecipado não sem estridência por um vasto arsenal de efeitos sonoros e pontuações de suspense, que, como sua deliberada premeditação e falta de sutileza, dá a impressão de ter sido diretamente contrabandeado de um melodrama apelativo.

Operando como um dos principais fios condutores para a trama do livro, que com frequência faz troça da previsibilidade e rigidez de tais mecanismos, não há dúvida que, ao colocar em primeiro plano esse jogo com as expectativas do leitor, essa canibalização do repertório de truques da indústria cultural é um dado que aponta para o estreitamento dessa Clarice "na ponta dos dedos" com a feição precária e intratável do seu presente, que encontra não por acaso nessa massa de clichês uma de suas decantações mais tangíveis. Com seu pendor a já nos entregar processado e mastigado o sentido dos fatos, tal cenário chega a ter mesmo algo de claustrofóbico no modo como as ações parecem ser aí todas rapidamente indexadas num minguado repertório de receitas prévias, desde a remissão autodepreciativa do livro à "história lacrimogênica de cordel" até passagens onde, quase como se perdesse de vez a paciência com esse calculado primarismo, o narrador parece simplesmente passar o carro na frente dos bois; pressa de que dá prova ainda a incessante proliferação de parênteses atravancando a narrativa. À medida que a história avança, contudo, e esses tropeços vão se tornando sistemáticos e ostensivos demais para ser só aleatórios, vê-se que esses mesmos dispositivos e raciocínios em piloto automático - ecoando por exemplo na definição do livro como uma "história com começo, meio e 'gran finale' seguido de silêncio e de chuva caindo" - vão se revelando pouco a pouco maleáveis a uma inesperada multiplicidade de usos, efeito que, de certa forma, tende a relativizar um pouco a referida impressão claustrofóbica, o mesmo valendo para o toque fatalista do anti-happy end. Assim, se pensarmos em como as abruptas modulações de tom chamam atenção sobre si - chegando inclusive a converter a redundância deliberada em estrutura de agressão, como é o caso da passagem em que o narrador brinca com uma lentidão quase sádica com o clichê do "quem espera sempre alcança" -, é quase como se, ao se expor com tanta ostensividade como metáfora gasta, useira e vezeira da pressa e falta de atenção daquelas que as empregam, o que poderia parecer numa 
leitura afoita um descuido estilístico terminasse gerando um certo recuo tático em relação à massa de clichês, cristalizada em artefatos que mal conseguem ocultar as suas frágeis costuras. Passando agora para um plano mais amplo, mas não necessariamente mais cômodo - com o foco menos no desconforto gerado por esses estranhamentos do que no modo como eles vão alocando em sistema os fatos narrados, tendo sempre como álibi a necessidade de se dobrar a uma suposta "convenção do gênero", que ainda não se sabe muito bem se é um melodrama ou uma história de cordel -, interessante notar ainda como, na medida em que funcionam como antecipação do que irá se seguir, tais remissões operam como um contrapeso neutralizante para a aparente desorientação da vOz narrativa, a qual, por sua vez, passando ao largo da profissão de onipotência do seu intróito, aparece assim como apenas a funcionária encarregada da execução de um golpe mais que surrado, cujo desfecho ele não faz a mínima questão de nos ocultar. Sem tornar-se em momento algum objeto de uma discussão explícita, essa permanente tensão entre fato e esquema narrativo - entre o suceder dos eventos e a soma de protocolos encarregados de lhes conferir ordem - coloca, por isso mesmo, toda a trama do livro sob a égide de um dilaceramento contínuo entre o que diz e o que mostra, dilaceramento cujo nó central, ao que parece, diz respeito a essa persistente dificuldade em dar crédito a uma voz manipulando convenções e dicções em que ela mesma não acredita, tendo sempre como nota dominante uma indigesta combinação de autoritarismo e pseudo-onisciência patente por exemplo no trecho em que se gaba de decifrar todo o mistério da "nordestina amarelada" apoiado num único olhar de relance. Permitindo-se ora a suspender a narrativa para uma digressão lateral, ora a enfatizar a importância de algo com uma indicação de explosão entre parênteses, é possível que o momento que escancara com mais lucidez a gravidade do impasse - diante do qual nunca sabemos direito quem age e quem sofre a ação - tenha lugar na estranha mudança de tom ocorrida quando o narrador trata de colocar em cena a morte de Macabéa; trecho em que, quase como se tivesse se convertido em servo dos próprios dispositivos que criou, Rodrigo parece quase nos pedir desculpas pela sua vontade de "adormecê-la" e "depois ir dormir". Seguida por páginas que vão esgarçando o máximo que podem o fio da sintaxe, até desaguar em parataxes que já não fazem qualquer questão de atenuar com conjunções e conectivos seu traço de enumeração caótica, a ponto de enfileirar uma digressão metalinguística com a constatação de que "é tempo de morangos", à sensação

1. LISPECTOR. A hora da estrela, p. 87. 
de inacabamento e inconclusividade que tudo isso provoca não é alheio o modo como, via de regra, as justificativas e ponderações de Rodrigo S. M. tendem a funcionar menos como uma asserção de domínio do que como uma deliberada autossabotagem, em trajetos que deixam notar exatamente o contrário do que se supõe que gostariam de dizer. Ou isso, no mínimo, é o que parece se dar nesse que é de longe um dos parágrafos mais constrangedores e venenosos de A hora da estrela:

Devo dizer que essa moça não tem consciência de mim, se tivesse teria para quem rezar e seria a salvação. Mas eu tenho plena consciência dela: através dessa jovem dou o meu grito de horror à vida. À vida que tanto amo. ${ }^{2}$

Ancorado num raciocínio que não tem qualquer prurido em fazer alarde de seu desleal excedente de visão - face a que Macabéa muitas vezes não parece ser mais que um rato de laboratório -, o trecho parece também desqualificar a si mesmo na indisfarçada incongruência dos nexos que instaura, começando pela comparação ao mesmo tempo ridícula e pertinente com a posição do bom deus até chegar na frase onde se tenta justificar a sucessão de desgraças em nome de um pretenso nobre propósito, num giro que, pelo instantâneo ceticismo que desperta, soa quase como uma tentativa de assassinato convertida em suicídio. Não parece muito difícil explicar porquê: afinal, se a intenção de sintetizar essa soma de fracassos patéticos em "grito de horror à vida” pode até ser um álibi aceitável para leitores que partilhem da misantropia e desatenção do nosso narrador - que está longe de primar pelo julgamento isento, no que concerne a Macabéa -, o mesmo já não se pode dizer entretanto do primeiro segmento sintático da frase, na qual, sem fazer qualquer esforço para esconder sua mão pesada, vemos o narrador mais uma vez tropeçar acintosamente nas suas próprias palavras, ao fazer da moça o mero veículo de transmissão de generalidades prêt-à-porter. De certa forma, com essa combinação de termos concebida para doer bem no fundo do ouvido do espectador médio, é como se, na medida em que trava a identificação automática com a voz incumbida de dar sentido aos fatos - e que nesse momento revela-se talvez por demais anti-estética para poder merecer nosso aval -, o livro nos impusesse então a necessidade de dar um passo atrás face a esse tropel de raciocínios defeituosos que Rodrigo nos

2. LISPECTOR. A hora da estrela, p. 33. 
despeja, tendo como chave de ouro um sintagma saído diretamente dos romances cor-de-rosa ("a vida que tanto amo"). Ato contínuo, no despudor e voracidade com que absorve os estilemas do kitsch, saltando do sádico para o paternalista quase sem mudar de linha e jamais perdendo a oportunidade de tentar construir mais uma pseudofrase de efeito, essa voz torna por isso mesmo particularmente cansativo o esforço de decifração do leitor, forçado a ter que se haver com juízos e comentários - se é que vemos bem - que, longe de jogar luz sobre a pretensa realidade que almejam arbitrar, funcionam antes como um pesado e opaco biombo nos separando dela. O que, diga-se de passagem, tampouco elimina a possibilidade de ler esse mesmo biombo em chave de sintoma, tendo como linha de fuga a própria feição móbil e perigosa daquilo de que este gostaria de nos proteger. Por aí se entende, em suma, como, tão ou mais importante que atentar para essas discrepâncias - convertidas em atalho para expor o funcionamento in loco de uma incansável máquina de autoengano - é não perder de vista também os fios soltos pendendo inassimilados nessas recorrentes mudanças de tonalidade da voz dominante, incumbida de tecer uma rapsódia que, mesmo jogando de modo premeditado com um elemento satírico - bastante notável na recorrência como o narrador se desautoriza a si mesmo com um bombardeio de racionalizações desengonçadas -, apresenta ainda assim momentos capazes de levantar a suspeita de que esse narrador talvez não seja tão cego e desatento como se poderia supor. Sem chegar a constituir propriamente a nota mais enfática do livro - que se em vários trechos parece fazer de Macabéa uma conformista visceral, em outros, como veremos, nos dá pistas bastante incisivas de que as coisas talvez não sejam tão simples quanto parecem -, trata-se de um aspecto que precisa ser antes desentulhado à força de uma pilha de conexões calcificadas; tarefa que pressupõe ainda a disposição a tirar as devidas consequências desse perseverante dissídio entre pretensão e performance que esta prosa assinala. Ou, o que não chega a ser exata e necessariamente a mesma coisa, entre aquilo que Rodrigo S. M. quer nos vender como o sentido último da história que conta e o peso potencialmente subversivo de algumas esparsas notações laterais, que tendem a ser negligenciadas e/ou sufocadas pelo constrangimento gerado por seus rompantes e poses, com direito a pérolas como "nimbo atordoado, entre o céu e o inferno", entre outras menos votadas: 
deuses que eu nunca descreva o lázaro senão morreria de lepra). (Se estou demorando um pouco em fazer acontecer o que já prevejo vagamente, é porque preciso tirar vários retratos dessa alagoana. E também porque se houver algum leitor para essa história, quero que ele se embeba da jovem assim como um pano de chão todo encharcado. A moça é uma verdade da qual eu não queria saber. Não sei a quem acusar, mas deve haver um réu). ${ }^{3}$

Trecho que sai como de hábito logo passando recibo de um duvidoso poder de empatia - ao mesmo tempo em que solapa a si mesmo na confusão um tanto ou quanto acintosa de dois episódios do evangelho ("Queiram os deuses que eu nunca descreva o lázaro senão morreria de lepra") -, o mínimo que se pode dizer, diante dele, é que sua postulação vai exatamente na direção inversa de nota dominante do livro, em que pese a frequência com que certas ações aqui migram de uma linha a outra da primeira para a terceira pessoa - sem que isso jamais configure de fato a pretendida dissolução de fronteiras de narrador e personagem. Se é que se trata mesmo de uma reivindicação "sincera". Em meio a um parágrafo que começa com uma frase praticamente ininteligível para quem quer que desconheça o que está antes, outro dado que ganha destaque, na disposição do trecho, é o modo evidentemente imperito como as duas digressões entre parênteses se afivelam, quase como se o narrador ainda não soubesse direito que informação priorizar; donde uma forma na qual, paradoxalmente, a dificuldade para dispor em sequência diacrônica dois comentários discrepantes torna-se o correlato de um excesso de possibilidades saturando e explodindo a tentativa de acomodar os fatos em sequência. Descontada a não pouca dificuldade envolvida nessa façanha - na qual a graça reside precisamente na capacidade de cristalizar no desenho truncado os movimentos confusos e imprevisíveis da ansiedade, diante de um objeto que parece colocar o narrador permanentemente na iminência de um ataque de nervos -, outro ponto que logo salta aos olhos, no relance final, diz respeito à estranha, para não dizer quase inverossímil, exatidão da frase presa e separada da diegese pelo segundo par de parênteses, onde pode-se identificar uma das sínteses mais bem acabadas do movimento do livro como um todo. Não por acaso, é um movimento reduzido, no trecho em questão, à mera tentativa de adiar um pouco um desfecho já prenunciado nos acenos com que Rodrigo tenta, com variáveis graus de êxito, lisonjear a

3. LISPECTOR. A hora da estrela, p. 38. 
platéia, colocada por este para assistir de camarote o itinerário de uma morte já anunciada; atitude ecoando ainda na hybris interpretativa com que tudo se fecha, quando reivindica-se a necessidade de delimitar uma causa específica para aquela angústia difusa ("Não sei a quem acusar, mas deve haver um réu"). Entre um extremo e outro, todavia, como um dado capaz de passar até desapercebido em meio à saraivada de hipérboles, destaca-se o trecho em que a demora surge justificada pela alusão à necessidade de ainda "tirar vários retratos dessa alagoana"; o que pode muito bem soar a princípio como apenas outra metáfora surrada. O mais impressionante, entretanto, é que, se lida como outro possível sumário da composição dos fatos em sequência, essa mesma imagem tem sem dúvida o efeito de relativizar um pouco a necessidade da solução já prevista, figurada desse modo menos como o telos final para onde tudo converge do que como um fecho colocado deliberadamente ad hoc para emprestar um pouco de definição àquilo que o próprio texto entrevê como um amontoar de cenas mais ou menos autônomas, ao estilo que alguém que simplesmente resolvesse dispor na página de um álbum uma sequência de fotos. Coincidência ou não, num livro que parece sustentar-se menos pela amarração de eventos do que pela reiteração diferida dos esquemas e estilemas fatalistas de gêneros da cultura de massa e/ou popular, o mais delicado que se pode dizer dessa passagem é que, ao colocar em primeiro plano a contingência e a falta de conexão dos fiascos de Macabéa - em cenas em que esta trafega da mera idiotia a um estoicismo digno de um clown beckettiano -, ela tende a pôr cada vez mais em dúvida a pretensa obrigatoriedade inapelável do seu atropelamento, que com isso parece dar-se a ver finalmente como solução postiça. Não obstante, sendo este atropelamento também por si só o emblema mais consumado de uma vivência de choque - a milhas de distância, portanto, de um fecho que operasse como arremate necessário de uma dada série de escolhas -, é preciso convir que, do ponto de vista de um espectador pouco afeito a incertezas e/ou ambiguidades, ele tem sem dúvida a vantagem de minimizar a inquietação provocada por lances que colocam em xeque a possibilidade de uma definição rígida, à exemplo do que dá azo à pergunta retórica com a qual a citação se encerra - quando toda a pletora de fatores concorrendo para a cristalização de um resultado cede terreno à busca entre regressiva e embotada de um culpado único. E, no entanto, que essa mesma caça desesperada de um bode expiatório seja ressignificada menos como uma tentativa de sanar a doença do que como o seu mais renitente sintoma, é uma hipótese insinuando-se em baixo contínuo no primarismo da 
maioria dos apartes do narrador, que chegam a quase reduzir a trama a um jogo de cartas marcadas, no qual a suposta intenção de imergir na opacidade do outro perde claramente espaço para o nada auspicioso deleite de Rodrigo S. M. com sua superioridade cognitiva a priori, vantagem que nesse caso tem menos a ver com empatia ou poder de penetração do que com o fato de que é ele quem aciona e manipula todos os fios da trama. Tomando-se como foco essa odiosa paródia de Tirésias que é Madame Carlota - a cartomante a quem Macabéa irá consultar pouco antes de morrer -, trata-se de uma superioridade bastante evidente, por exemplo, no momento em que o narrador Rodrigo S. M identifica nesse episódio o ponto mais alto da vida de Macabéa - no que se pode ler também a nada discreta prolepse de sua queda próxima, a ter lugar numa cena, como se verá, que, justo por produzir outra simetria perfeita demais para poder ser crível, acabar por desdizer ponto por ponto todas as predições da dublê de oráculo. Em escala bem mais reduzida, aliás - embora em nada menos crucial para a economia perversa da trama -, isso reverbera ainda no comentário casual de Madame Carlota sobre a moça a quem teve "a franqueza de dizer" que ia ser atropelada, passagem na qual se pode identificar outra piscada de olho para o auditório convertido em voyeur sádico dos percalços de Macabéa. Num estilo que por isso mesmo parece tornar-se cada vez mais interessante e complexo quanto mais rateia, impossível não destacar, finalmente - como um trecho capaz de condensar de modo telegráfico toda a lucidez e turvação que atravessam a história -, a passagem na qual Rodrigo dá a impressão de querer fazer valer o estardalhaço da menção ao tecnicolor bem nas primeiras páginas, naquela que é, sem favor algum, uma de suas mais explícitas e desastradas operações de usura semântica:

Macabéa ao cair ainda teve tempo de ver, antes que o carro fugisse, que já começavam a ser cumpridas as predições de Madama Carlota, pois o carro era de alto luxo. Sua queda não era nada, pensou ela, apenas um empurrão. Batera com a cabeça na quina da calçada e ficara caída, a cara mansamente voltada para a sarjeta. E da cabeça um fio de sangue inesperadamente vermelho e rico. O que queria dizer que apesar de tudo ela pertencia a uma resistente raça anã teimosa que um dia vai talvez reivindicar o direito ao grito. ${ }^{4}$

4. LISPECTOR. A hora da estrela, p. 80 . 
Como se vê, tendo como fecho uma rima toante digna de um campeonato de cordel, a passagem dá uma boa ideia da desenvoltura com que a voz narrativa salta sem cuidado de um golpe de onisciência para a generalidade, tendo agora como suporte um trajeto que, iniciado com a exploração in extremis do velho tema trágico da leitura equivocada de um sinal, desemboca depois numa cena de um reconhecimento que é também um dos melhores lances de humor negro de A hora da estrela. Uma vez amortecido porém o impacto do chiste pelo qual a catástrofe converte-se perversamente em outro endosso em cores berrantes do que já havia sido previsto -, a frase dobra-se por fim num enunciado que especifica com precisão quase cirúrgica a posição do cadáver, para logo depois dar lugar a uma parataxe roçando de novo perigosa e calculadamente a linha do kitsch, em sua ênfase posta sobre a vermelhidão e riqueza de que seria portador o tal "fio de sangue". À primeira vista, aliás, no momento em que o detalhe é mais uma vez convertido em fachada de um sentido genérico - signo de resistência e não de derrota -, a impressão é de que o livro parece ter perdido em definitivo o controle de si mesmo, levando ao paroxismo a compulsão do narrador a pregar autoritariamente sentidos arbitrários em tudo que vê pela frente. Passado esse primeiro desconforto, entretanto, intrigante notar como, no limite, o desassossego gerado por pequeno show privé de discricionarismos aparece nesse trecho sofrendo a contrapressão da deliberada falta de elegância de sua última frase, de que dão prova tanto o efeito de gagueira gerado pela repetição dos "quês" quanto a bizarra indiscrição desse "O que queria dizer" cingindo uma frase a outra, gesto que parece de novo desafogar de modo não muito educado o trabalho interpretativo do leitor. Se tomado apenas por seu valor de face, é certo que essa junção tende apenas a reforçar ainda mais a pouca desenvoltura do narrador no trato com as palavras; e, contudo - ao funcionar como um perfeito exemplo de tudo o que não deve fazer um escritor moderno; quase uma ofensa flagrante à inteligência do seu público -, o eco desagradável produzido pelas quatro palavras sela também a definitiva destituição da vOZ narrativa enquanto instância confiável. Supondo-se que se trate mesmo de um fracasso consciente, no caso específico dessa parábase, é um efeito que passa antes de mais nada pela dificuldade em fazer com que os eventos postos em cena falem por si mesmos, impasse capaz de engatilhar então a intervenção intrusiva do narrador, que agora parece ter batido todos os recordes no quesito falta de tato. Numa leitura mais piedosa, entretanto, ao dar a si próprio ares de cantor de cordel, é bem provável que ele esteja apenas sucumbindo de novo à 
tentação de perpetrar mais uma rima barata, hipótese que, mais uma vez, põe na berlinda a seriedade desse desastrado rascunho de salto ao universal que o trecho nos expõe, legível desse modo como apenas mais um recurso para tentar polir a aspereza do mundo com a ajuda de uma pequena melopeia. Vale observar ainda - e difícil saber até que ponto se trata ou não de um efeito calculado - que, ao funcionar quase como um perfeito antimanual da arte de obter crédito e complacência do seu leitor hipócrita - reunindo em pouco mais que uma dezena de linhas uma extraordinária sequência de trapalhadas sonoras, sintáticas e semânticas -, esse trecho torna quase inevitável o confronto com a estrofe final de um poema que parece ser aí evocado, quase como um horizonte inatingível, na fala da voz dominante - e mais uma vez, num registro que não parece nem um pouco abonador para Rodrigo S. M.:

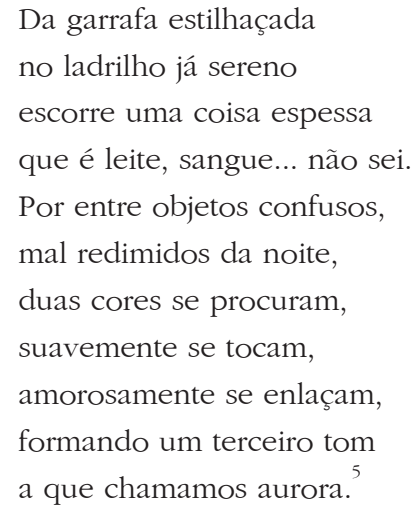

Com versos que reverberam estranha mas nitidamente no parágrafo de $A$ hora da estrela há pouco citado, essa estrofe retirada de "Morte do leiteiro", um dos poemas mais emblemáticos e bem-sucedidos de $A$ rosa do povo, pode soar à primeira vista como uma arrasadora peça de acusação à desajeitada extravagância cromática de Rodrigo S. M., ao esbanjar todo o tato e controle de ritmo que faltam a esta. Arrematando uma cena não menos patética e absurda do que aquelas protagonizadas por Macabéa, nas cinco estrofes anteriores à acima transcrita, o poema narra com pungência e sobriedade a morte acidental de um leiteiro confundido com um ladrão por um proprietário insone, que aliás nem se dá ao trabalho de socorrer depois sua vítima inocente ("Quem quiser que

5. DRUMmOnd DE ANDRADE. Poesia 1930 - 1962, p. 410 - 411. 
chame o médico/ polícia não bota a mão/ neste filho de meu pai."); detalhe que só torna ainda mais chocante e revoltante a conclusão da história, cujo ponto de partida remete a nada mais, nada menos que um mero boato ("ladrões infestam o bairro"). Até que o desastre se consume, entretanto, o cuidado com que o poema expõe um a um todos os antecedentes do caso faz com que sejamos colocados, quase sem notar, numa espécie de exotopia ideal em relação a ele; o que a princípio nada parece ter a ver com a violência como, em $A$ hora da estrela, é-se a cada página distraído pelas intromissões e apartes do narrador, que se interpõem como um vidro embaçado entre o nosso posto de observação e o de Macabéa. Por outro lado, no equívoco que em Drummond dá ignição ao pavoroso "incidente" - resultado da inépcia para distinguir projeção e percepção, em meio ao lusco fusco - não é difícil identificar a dramatização de uma crise muito parecida à que perpassa de fora a fora a ação de $A$ hora da estrela, e na qual reverbera a perda de um mínimo denominador comum capaz de viabilizar o contato civilizado entre estranhos. No que diz respeito especificamente à construção do poema - com sua asfixiante figuração de um mundo sobressaltado de cima a baixo pelo medo, mesquinharia e desconfiança, e sua não menos espantosa particularização desse impasse na forma do mais prosaico fait divers -, trata-se de um déficit que, com a cumplicidade de outros espectadores tão sonsos e desmemoriados quanto o nosso pequeno assassino, irá acarretar então o sacrifício arbitrário e evitável da parte mais fraca, logo amenizado por uma racionalização que de novo coloca no centro da cena a onipresença do autoengano ("Está salva a propriedade"), num desenho que apenas torna ainda mais gritante a injustiça e a falta de sentido da morte. No poema como um todo, porém, é como se essa mesma falta de sentido tão irredimível só emprestasse um impacto ainda mais duradouro a esse pequeno lampejo de substância que parece arredondar seu desfecho, na estrofe em que o sangue e o leite surgem quase apaziguados e imbricados como numa dança erótica. Apenas que, por mais tentador que seja ler nessa suposta aurora um signo de esperança, trata-se de uma possibilidade sempre-já devidamente relativizada pela ironia ao mesmo tempo límpida e indignada como os fatos se dispõem, e em meio à qual esse sentido surge apenas como um desenho constelar momentâneo, que, exatamente por não ter mais a participação de qualquer desejo humano - emergindo a partir de uma conjunção fortuita de matérias literal e figurativamente estilhaçadas - só faz tornar ainda mais intoleráveis a degradação, o horror e a pusilanimidade dessa morte anônima. Em compensação, se levarmos em conta o perigo envolvido nesse 
tipo de sucesso estético, patente no virtuosismo com que esses versos jogam uma nota de pacificação sobre a violência narrada, deve-se também reconhecer que, ao passar bem ao largo de incômodos como os provocados pelo texto clariciano, eles concorrem de certo modo para amenizar a rudeza dessa cisão comunitária, sem prejuízo de todo o poderoso estranhamento e indignação que provocam. Numa possível tentativa de comparação, portanto - e nisso não vai certamente qualquer juízo de valor -, na medida em que devem sempre cavar sua linha de fuga para além de possíveis intimações conciliatórias, é um pouco como se os impasses provocados pelos dois textos servissem, em última análise, para figurar a apresentação do homo sacer como um insolúvel jogo-de-empurra entre o leque de estratégias formais e a matéria tratada, no qual cabe a cada um desses polos relativizar e problematizar as reivindicações do outro. A estar correto esse raciocínio, portanto, o que poderia parecer à primeira vista signo de fraqueza - se pensarmos no modo como os versos de Drummond nos coagem a reconhecer toda a falta de jeito dos apartes de S. M. - torna-se por via transversa uma tática para dar conta de um mundo em que parece ser cada vez mais difícil traçar uma linha nítida entre o que se projeta e o que se percebe, entre o que emerge como a mera ilusão engendrada por um corpus de presunções a priori e a esperança de se encontrar um fundo rochoso para além de camadas e camadas de ideias feitas, convertidas não por acaso na matéria-prima por excelência das frases do narrador de Clarice.

Aos interessados em sondar todas as implicações desse mecanismo cego - com seu pendor a sempre compreender depressa demais tudo o que lhe aparece -, parece quase fora de dúvida, portanto, que se há um ponto especialmente delicado da empreitada como um todo, este diz respeito justamente à perigosa proximidade que esta prosa mantém com o fracasso estético, impressão que, longe de constituir de fato uma deficiência, só faz sobressair ainda mais a aposta original e arriscadíssima desse livro ímpar, construído ao estilo de uma bricolagem virtuosística de sucata ideológica, com uma radicalidade que não teme fazer tábula rasa do próprio bom gosto. Transposto esse primeiro obstáculo, contudo - cujo efeito é nos coagir a ler sempre de forma enviesada as dicas do narrador -, creio que é quando também se pode então começar a perceber como, em paralelo aos sucessivos passos em falso do mestre de cerimônias, corre ainda um apelo para que se preste atenção ao que acontece de modo menos chamativo no fundo da cena, nos raros momentos em que o narrador limita-se a expor sem julgar os diálogos de Macabéa, os quais, uma vez devolvidos à sua 
limpidez, tendem assim a fazer as vezes de pequenas clareiras ventiladas ao longo da trama. De fato, em que pese os não poucos entimemas conformistas em que a personagem recai, não é absurdo supor que, se tivermos em conta o que fica ainda pairando no ar depois de cada intromissão, ela, com seu "sorriso idiota" e "cara que pede tapa", aparece nesses diálogos protagonizando gags no mínimo desconcertantes, nas quais um automatismo que não se sabe se é fruto de inocência ou de parvoíce se dá as mãos com a perturbadora mania de Macabéa de "prestar atenção em coisas insignificantes"; gosto que vai aliás exatamente na contramão da volúpia generalizadora de Rodrigo S. M., que a certa altura chegará a se gabar de ter captado toda a alma da jovem nordestina amarelada num único olhar de relance. Concorde-se ou não com tal assertiva - e no livro não faltam evidências contundentes para relativizá-la -, é necessário reconhecer, no entanto, que, se tomarmos como parâmetro toda a não pouca irritação provocada pela irresistível inclinação de Rodrigo ao autoelogio, esta parece muitas vezes quase inócua no cotejo com os pequenos blecautes provocados pelas falas de Macabéa, como é o caso daquele em que nota a incongruência de um casaco de pele no calor do Rio de Janeiro, ${ }^{6}$ ou daquele em que simplesmente se limita a devolver à sua colega Glória a pergunta agressiva (“Ser feia dói?”). Sem que seja possível nisso identificar com clareza um projeto consciente - já que nesses momentos o narrador se mantém em geral em silêncio sobre o que se passa na cabeça da personagem -, são cenas nas quais, repetida e sistematicamente, a insuperável dificuldade da protagonista de se ajustar ao mundo parece instaurar à revelia de si própria breves crises sensório-motoras no centro da ação do livro, ao trazerem à luz os nós mais frágeis e inexaminados de frases concebidas com o deliberado propósito de rebaixá-la ou apenas enganá-la. Lembrando em alguns momentos o desengonço de alguém tentando falar pela primeira vez uma língua estranha, e em outros o de um palhaço às voltas com um novo objeto cuja função desconhece, trata-se de um aspecto, para dizer o mínimo, que, depois de desconcertar logo no início do livro o chefe de Macabéa e levar Olímpico quase às vias de fato em uma longa e genial cena de diálogo, encontra talvez seu ápice na passagem em que o metalúrgico resolve terminar de vez o namoro com Macabéa, o que acabará conduzindo a nossa heroína a mais outra reação imprevista:

6. LISPECTOR. A hora da estrela, p. 77. 
$\mathrm{Na}$ hora em que Olímpico lhe dera o fora, a reação dela (explosão) veio de repente inesperada: pôs-se sem mais nem menos a rir. Ria por não ter se lembrado de chorar. Surpreendido, Olímpico, sem entender, deu algumas gargalhadas.

Ficaram rindo os dois. Aí ele teve uma intuição que finalmente era uma delicadeza: perguntou-lhe se estava rindo de nervoso. Ela parou de rir e disse muito, muito cansada:

- Não sei não...'

Além de ecoar de modo inequívoco a já citada cena com o chefe - quando nós a veremos desconcertá-lo com seu riso inexpressivo e excesso de gentileza -, a passagem dá a impressão de redesenhar com um único lance todo o sentido e funcionalidade desse riso fora de hora, transformado agora menos numa reação natural face ao imprevisto do que no índice de uma espécie de intensidade assemântica decididamente refratária a clichês de melodrama, mas à qual Olímpico tentará depois a seu modo conferir sentido, num gesto que de certa forma reproduz em escala menos titânica a obsessão generalizadora do narrador masculino. De início mantendo-se um respeitoso e conveniente silêncio diante da ação, é interessante perceber, ainda, como, na medida em que vai se instaurando o constrangimento, esse narrador irá logo abandonar essa postura em favor de mais outra racionalização preguiçosa ("ria por não ter se lembrado de chorar"), dando ensejo a uma frase que se mantém felizmente incapaz de consertar a fratura exposta aberta pelo inigualável desconforto da cena. Num livro que parece muitas vezes promover o aborto sistemático de toda as suas potenciais epifanias - bastando que se pense por exemplo no modo como queima como fogo de palha o encontro de Macabéa com o rinoceronte, descrito por ela como uma espécie de "erro de Deus" -, este é um trecho que, com sua marcação de cinema mudo e tom quase farsesco, mais uma vez reforça a distância dessa Clarice tardia das vertigens e mergulhos introspectivos dos anos 40 e 50, cedendo vez agora à ênfase sobre uma certa objetividade exteriorizada ao estilo de sketch cômico, numa tocada que coloca portanto muito mais foco na precisão do gesto do que nas camadas de ressonâncias deste sobre seus agentes. Em mais de um aspecto, por sinal, na medida em que não se consegue aqui atrelar esse riso fora de hora a uma teleologia aceitável, tal ênfase tende a também

7. LISPECTOR. A hora da estrela, p. 71. 
dilatar exponencialmente a força e ambiguidade da suposta reação imbecil, ao colocar-nos diante de uma personagem que, justo por estar inapta a responder da forma mais adequada às "n" situações estereotipadas nas quais o livro a coloca, passa por isso mesmo a operar na contracorrente do incontrolável desejo de seu criador de fixar seu significado. A fortiori, é um propósito que já aparecia como programa confesso desde as primeiras páginas de $A$ hora da estrela - e mais especificamente no parágrafo onde, comentando e justificando a bizarra pontuação de um dos títulos do livro ("Quanto ao futuro."), Rodrigo defende a superioridade do ponto final sobre a reticência - sem que seja todavia possível captar ainda toda a ressonância sinistra dessa predileção. Não obstante, se também aqui o narrador de novo não chega a convencer-nos como gostaria, ao adotar um jargão que soa como outra inexcedível amostra de canastrice verbal ("Se em vez de ponto fosse seguido por reticências o título ficaria aberto a possíveis imaginações vossas, porventura até malsãs e sem piedade.”), parece-me que isso se dá bem menos por um eventual descontrole da organização da narrativa do que pela habilidade como, em $A$ hora da estrela, essas fendas que abrem pequenas zonas de incerteza em meio à massa de clichês se deixam ver também como uma lição de leitura nos seus próprios termos, tendo como pivô essa espécie de Virgílio às avessas que é o narrador masculino. O mesmo narrador, contudo, que nos raros momentos em que deixa de comentar as cenas que narra - e às quais evidentemente só temos acesso graças à sua mediação - é também quem nos fornece as evidências suficientes para desautorizá-lo. Sem chegar exatamente a adquirir o peso melodramático de um desmascaramento - funcionando sobretudo como pequenas pontuações dissonantes que interrompem e/ou suspendem certezas -, entre os vários aspectos notáveis dos trechos há pouco evocados, nos quais Macabéa parece desarmar quase sem se dar conta seus virtuais agressores, inevitável destacar o modo a um só tempo sutil e preciso como, ao devolver a cada gesto a sua ambiguidade, eles atestam, quase como uma nota surda, o total fracasso das pretensões de controle do narrador tagarela, posto agora diante de uma situação que se mantém teimosamente a salvo de suas tentativas de colonização semântica. Mais que isso: no efeito ao mesmo tempo prosaico e incisivo desses respiros cômicos, pode-se reconhecer um veio que corre em subterrâneo à nota dominante do livro, nos muitos momentos em que parece nos fazer crer que a história caminha para um desfecho inexorável. Tomada alguma distância, entretanto - e por mais que eventualmente possamos até sucumbir ao peso e insistência de seu narrador hiperativo, aí acumulando as funções de 
intriguista e raisonneur, de carrasco e mestre de cerimônias -, curioso ainda notar como, depois de nos forçar a rejeitar muitas das afirmações mais convictas de sua primeira pessoa, o texto acabe deixando a nosso critério a tarefa de decidir qual é o peso relativo de cenas como a acima transcrita, na qual o riso surge como um rasgo rigorosamente infenso às racionalizações disponíveis. Mesmo se, para colocar em primeiro plano esse tipo de efeito, seja preciso ter no mínimo a mesma atenção ao detalhe insignificante da protagonista feminina do livro; capacidade que, a julgar pela pressa que contagia de fora o trabalho de narração, não parece ser um item muito difundido nesse mundo em que todos sofrem de forma quase incurável de horror ao vácuo - coisa que evidentemente está longe de resguardar esse mundo de certas infiltrações oblíquas.

Tendo-se em vista ainda o modo como Macabéa insiste em sempre desvencilhar-se em última instância de toda definição - ao mesmo tempo em que se nos oferece como a vala comum em que todos os preconceitos e projeções se despejam -, outra forma de dar conta de tais desacertos pode ser entendêlos como um índice sinalizando para o suposto outro do texto como um objeto definitiva e inapelavelmente perdido, constatação que parece reverberar ainda nas entrelinhas de todas as intervenções do narrador, que ganham com isso ares de aprisionamento autoimposto - na exata torção pela qual nos fornecem elementos suficientes para poder enxergar além dela. Diante de um livro que se coloca desde a sua primeira carta de intenções como veiculando "um sentido secreto que ultrapassa palavras e frases" - pouco importa também a insistente violência como o modo de dizer acaba aqui cancelando e/ou explodindo o sentido do que se diz -, não parece que estejamos apenas diante de um mero efeito arbitrário; e, todavia, se há um ponto que contribui de forma particularmente incisiva para colocá-lo em destaque, este não diz senão respeito à intrigante insistência como, tendo sempre como foco um contínuo desacerto entre o julgar e o mostrar entre o bombardeio de sínteses apressadas e possibilidades que muitas vezes cintilam brevemente por detrás dessa pilha de escombros -, a sua protagonista parece, na citação acima, pôr em xeque a pretensão de superioridade do seu criador, para se dar a ver então muito menos como um brinquedo dócil que como uma mancha difusa, capaz por isso mesmo de amplificar e denunciar o fracasso de cada operação projetiva. Por mais que esteja longe de tornar o livro menos opaco, isso tem sem dúvida um peso decisivo no modo como, na cena em que hesita em dar cabo de Macabéa, esse mesmo narrador finge resignar-se a apenas narrar e consumar o que já se pressentira - evocando seja a obrigação 
de fazer jus a supostos "fatos-pedras" que antecedem e condicionam o jogo da enunciação, seja a de simplesmente dobrar-se a uma convenção de gênero. Na melhor das hipóteses, entretanto, são metas que, longe de encontrar respaldo no que o livro mostra, operam de um modo geral como desculpas desqualificando a si mesmas no exato instante em que se enunciam, sem chegar a exatamente opor efetiva resistência ao desfecho fatalista da trama. E ainda assim, a julgar pela não pouca angústia e perplexidade que o seu percurso provoca - nas passagens em que um riso ou fala de Macabéa jogam de chofre por terra todo o palavrório -, é certo que esse desfecho torna imperativa também uma leitura de viés, na qual, aos poucos, a consistência que vão adquirindo tais detalhes nos dá munição para traçar uma linha de fuga capaz de furar o bloqueio e a tutela do narrador S. M., cuja paciência parece estar sempre à beira de um colapso diante dessa criatura paradoxalmente frágil e forte, concreta e evasiva que é Macabéa, com sua infalível vocação para tornar perigosamente esfumada a linha entre a resistência e a idiotia, entre a passividade e a paciência infinita. Traços pelos quais, como se vê, ela se coloca claramente nos antípodas do seu afobado demiurgo. Nada a espantar, enfim, que, após tantas tentativas inglórias de chegar a bom termo com ela, não reste a este nenhuma outra saída senão matá-la.

The devil, probably: mourning and communal splitting in Clarice Lispector's A hora da estrela.

Abstract: A reading of Lispector's A hora da estrela, this essay analyses the rhetorical and political fractures pervading the plot, taking as a starting point the intrusive and self-debunking strategies of its narrator.

Keywords: Community, Alterity, Representation.

$$
\text { Referências }
$$

ADORNO, Theodor \& HORKHEIMER, Max. Dialética do esclarecimento. Rio de Janeiro: Jorge Zahar, 1997.

AGAMBEN, Giorgio. Homo sacer: Belo Horizonte: UFMG, 2004.

AREAS, Vilma. Clarice na ponta dos dedos. São Paulo: Companhia das Letras, 2006.

DELEUZE, Gilles. A imagem-tempo. São Paulo: Brasiliense, 1990. 
Belo Horizonte, p. 133-153

DRUMMOND DE ANDRADE, Carlos. Poesia 1930-1962. São Paulo: Cosac \& Naify, 2012. FREUD, Sigmund. O homem dos lobos e outros textos. São Paulo: Companhia das Letras, 2010.

GIRARD, René. A violência e o sagrado. São Paulo: Paz e terra, 1996.

LISPECTOR, Clarice. A hora da estrela. Rio de Janeiro: José Olympio, 1977.

MENDES DE SOUSA, Carlos. Clarice Lispector: figuras da escrita. São Paulo: IMS, 2011. MOSER, Benjamin. Clarice, uma biografia. São Paulo: Cosac \& Naify, 2009.

SCHWARZ, Roberto. Um mestre na periferia do capitalismo. São Paulo: Duas cidades, 1990. 
